\title{
EPILEPSZIÁS AGYI HÁLÓZATOK EGYSEJT-AKTIVITÁSÁNAK JELLEMZÉSE HAWKES-FOLYAMATOK SEGÍTSÉGÉVEL
}

\author{
PERCZEL GYÖRGY, ERŐSS LORÁND, FABÓ DÁNIEL, GERENCSÉR LÁSZLÓ, HAJNAL \\ BOGLÁRKA, SZABÓ CSILLA, VÁGÓ ZSUZSANNA, WITTNER LÚCIA
}

$\mathrm{Az}$ epilepszia az egyik leggyakoribb idegrendszeri megbetegedés, mely mintegy 50 millió embert érint világszerte. A betegek életminőségének javítására egy ígéretes, fejlesztés alatt álló technológia az ún. zárt hurkú neurostimulátorok alkalmazása, melyek révén a rohamok kifejlődése jó eséllyel megakadályozható. Az ilyen típusú eszközökben kritikus tényező a rohamok előrejelzése agyi elektromos jelek alapján. Az idegsejtek tüzelési mintázatainak modellezéséhez a pontfolyamatok elmélete által felkínált keretrendszert, ezen belül a Hawkes-folyamatok elméletét alkalmazzuk. Jelen dolgozatban valós idegsejtek tüzelési mintázatait elemezzük, Ozaki - exponenciális válaszfüggvényel leírható Hawkes-folyamat esetére kidolgozott - maximum likelihood (ML) módszerének implementálásával és kiterjesztésével.

\section{Bevezetés}

\subsection{Az epilepszia rövid ismertetése}

Az epilepszia előfordulási gyakorisága 0,5-1\%, mellyel ez az egyik leggyakoribb idegrendszeri megbetegedés. A betegség legfőbb jellegzetességei a visszatérő rohamok, melyek az egyes izomcsoportok körülírt rángásaitól az átmeneti eszméletvesztésen keresztül a legismertebb tónusos-klónusos nagyrohamokig változatos formákban jelentkezhetnek. A gyógyszeres és sebészeti kezelési lehetőségek ellenére a betegek körülbelül 30\%-ánál nem érhető el megfelelő rohamkontroll.

A rohamok váratlansága olyannyira befolyásolja a betegek jóllétét, hogy önmagában a rohamszám csökkenése kevéssé javítja az életminőségüket - még ritkán jelentkező rosszullétek esetén is az ezektől való félelem szervezi az életüket [12]. Épp emiatt általánosan elfogadott az a feltételezés, hogy egy rohamokat előrejelző rendszer nagyban hozzájárulna az életminőség javulásához, arról nem is beszélve, hogy egy elektromos stimulátor vagy gyógyszeradagoló pumpa hozzákapcsolása révén akár a rohamok kifejlődését is megakadályozhatná [4]. 


\subsection{Zárt hurkú neurostimulátorok az epileptológiában}

Az epilepsziás rohamok előrejelzésére számos módszert javasoltak a szakirodalomban, ld. [4]. Ezek tipikusan az agyi elektromos jelek (EEG, electrocorticogram vagy ECoG) elemzésén alapulnak. Fokálisan (egyetlen körülírt agyterületről) induló rohamok esetén feltételezhető, hogy a rohamok idegrendszeri események kaszkádjaként fejlődnek ki, ezért - bár a kezdetüket megelőző specifikus jellemzőről nincs tudomásunk - elvileg elörejelezhetők. Ugyan az elmúlt években megfogalmazott statisztikai követelményeket (above chance) néhány módszer teljesítette, a klinikai alkalmazhatóság számára ennél szigorúbb kritériumokra lehet szükség.

Napjainkban egyetlen sebészileg beültethető, zárt hurkú eszköz található a piacon, a Responsive Neurostimulation (RNS, NeuroPace, Mountain View, CA, USA). Ez „mindössze” detektálja, és nem prediktálja a rohamokat, majd stimulálja a roham indulásáért felelös agyterületet. Ezzel szemben a Seizure Advisory System (NeuroVista, Seattle, WA, USA) valódi rohampredikciót céloz meg, de ez a készülék egyelöre nem került kereskedelmi forgalomba [4].

Mivel az eddig megjelent rohampredikciós eszközök döntően a helyi mezőpotenciálok (local field potential, LFP) elemzésén alapulnak, felmerül a kérdés, hogy vajon egyéb, szintén az agyi elektromos aktivitásból származtatható jelek, így az egy -, és soksejt-aktivitás használható-e a rohamok előrejelzésére. A következőkben röviden ismertetjük ezeket és az epilepszia szempontjából releváns jellemzőiket.

\subsection{Egysejt-aktivitás az epilepsziában}

Mivel az idegsejtek egymás között akciós potenciálok (AP) révén kommunikálnak, az egyes sejtek által létrehozott AP-sorozatok alapvető fontosságúak az ideghálózatok müködésének megértésében. A sejten kívül regisztrált elektromos jelekből, 200-500Hz feletti felüláteresztő szürő alkalmazása révén olyan idősorokat nyerhetünk, melyek elsősorban a regisztráló elektród közvetlen környezetében található sejtek akciós potenciáljait tartalmazzák (populációs sejtaktivitás, multiunit activity, MUA). További feldolgozás (spike-sorting) révén ezek az akciós potenciálok, tüzelési mintázatok lényegében egyes sejtekhez rendelhetőek (egysejtaktivitás, single-unit activity, SUA).

Az epilepsziás rohamok neuronális eredetének egy korai állatkísérletes bizonyítéka a sejtek tüzelési mintázatainak rohaminduláskor megfigyelt változása volt. Egy kurrens, humán mérési eredményeken alapuló elmélet szerint az epilepsziás roham tér-időbeli terjedése két állapottal jellemezhető. A túlserkentett, ún. „iktális core" területen a sejtaktivitás jelentősen megemelkedik, hiperszinkronitást mutat, és a neuronok egymástól elkülönült akciós potenciálok helyett sorozatokban, ún. burst-üzemmódban kezdenek tüzelni. A környező gátolt ún. „iktális penumbrá"-ban jóval heterogénebb marad a sejtek tüzelési mintázata [9].

Az általunk mért jellemző sejtaktivitás változást az 1. ábra mutatja be. Ezen az agykéreg egy körülírt területéről induló epilepsziás roham elektromos mintá- 
zata látható, a piros nyíl a roham kezdetének időpontját jelöli. Az agykéregbe idegsejtek tüzelésének detektálásra is alkalmas ún. intrakortikális rétegelektróda lett beültetve. Az innen nyert adatsort az (a) ábrarészlet mutatja. A detektált AP-ok morfológiája alapján végzett spike-sorting a (b) ábrarészleten látható. Így a c1, c2, c3 jelölésű idegsejtek aktivitását egyedileg vizsgálhatjuk, ld. (c) ábrarészlet.

A válogatott sejtek aktivitását bemutató ábrarészleten jól látszik, hogy míg egyes neuronok a rohamindulástól függetlenül folyamatosan, „nyugalmi” állapotban is aktívak (c1, sötétkék), addig mások a roham kezdetét követően aktiválódnak (c3, világoskék), vagy azt követően fokozódik az aktivitásuk (c2, zöld).

a

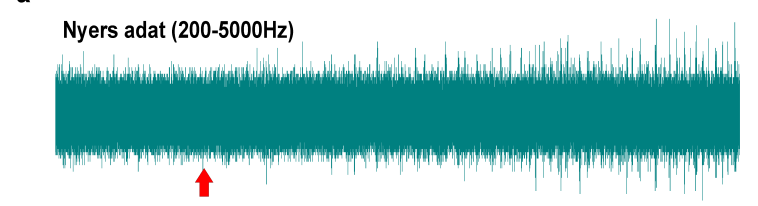

C

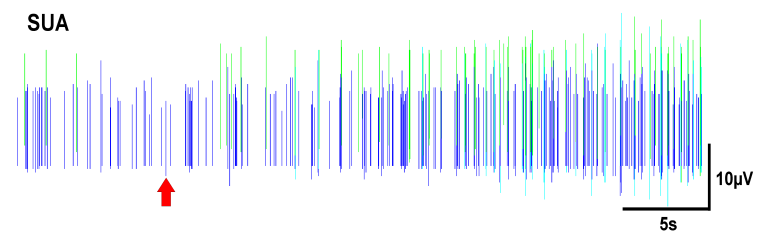

b

A válogatott idegsejtek akciós potenciáljai
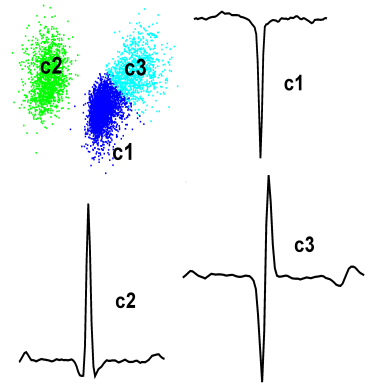

1. ábra. Epilepsziás roham indulásakor mért sejtaktivitás.

\section{Hawkes-folyamatok az egysejt-aktivitás modellezésére}

Az akciós potenciálok időpontjai által definiált idősort egy ún. pontfolyamattal modellezzük. Matematikailag ez véletlen események $T_{n}$ időpontjainak szigorúan növekedő, $0=T_{0}<T_{1}<T_{2} \ldots$ sorozata, amelynek nincs torlódási pontja. A matematikai kezelhetőség szempontjából hasznos megengednünk kétoldalú, $\left(T_{n}\right),-\infty<n<\infty$ folyamatokat is, amelyek értéktartománya $(-\infty,+\infty)$. A témakör kitünő bevezetését adja [1].

Egy pontfolyamat alternatív leírását adja a számláló folyamat, amelyet egy $(a, b]$ intervallumra az $N(a, b]=\#\left\{n: a<T_{n} \leq b\right\}$ egyenlöséggel definiálunk. Egy pontfolyamat $t$ idő elötti történelmét az

$$
\mathcal{F}_{t}=\sigma\{N(a, b]: a<b \leq t\}
$$

$\sigma$-algebra definiálja. 
Egy $\left(f_{t}\right) \geq 0, t \geq 0$, ún. jósolható függvény $N($.$) pontfolyamat szerinti integ-$ rálját az

$$
\int_{0}^{\infty} f_{t} d N_{t}=\sum_{n \geq 0} f\left(T_{n}\right)
$$

egyenlőséggel definiáljuk. (A jósolhatóság heurisztikus jelentése: $f_{t}$ előáll, mint $\mathcal{F}_{t}$-adaptált, balról folytonos folyamatok limesze.) Megmutatható, hogy az $N($. pontfolyamathoz létezik egy akár jósolhatónak is választható ún. intenzitásfüggvény, amely eleget tesz az alábbi azonosságnak:

$$
\mathrm{E}\left(\int_{0}^{\infty} f_{t} d N_{t}\right)=\mathrm{E}\left(\int_{0}^{\infty} f_{t} \lambda_{t} d t\right) .
$$

Az idegtudományokban kitüntetett szerepe van az ún. öngerjesztő (self-exciting vagy mutually exciting) pontfolyamatoknak, vagy ún. Hawkes-folyamatoknak, ld. [7], továbbá [1], [2], [6] és [5], amelyek az egymással hálózatba kapcsolt idegsejtek akciós potenciáljait modellezik. Egy kétoldalú, többváltozós $\left(T_{i, n}\right), i=1, \ldots, k$, pontfolyamat Hawkes-folyamat, ha az $N_{i}($.$) számlálómértéke eltolásinvariáns, és a$ $\lambda_{i, t}$ intenzitásfüggvénye eleget tesz egy

$$
\lambda_{i, t}=\mu_{i}+\sum_{j=1}^{k} \int_{-\infty}^{t} g_{i j}(t-s) d N_{j, s}, \quad \mu_{i}>0, g_{i j}(u) \geq 0
$$

egyenletrendszernek. Itt $\mu_{i}$ a háttérintenzitásokat jelöli, $g_{i j}(u)$ pedig nemnegatív impulzusválasz-függvényeket (IRF) jelöl. Egyetlen idegsejt tüzelési mintázatának (egysejt aktivitás) modellezésére az egydimenziós Hawkes-folyamatot alkalmazzuk, amelyet implicit módon az alábbi zártkörü rendszer definiál:

$$
\lambda_{t}=\mu+\int_{-\infty}^{t} g(t-s) d N_{s}, \quad \mu>0, g(u) \geq 0 .
$$

$\mathrm{Az}$ (1) egyenlet mindkét oldalának várható értékét véve, a $\bar{\lambda}=\mathrm{E} \lambda_{t}$ jelöléssel a $\bar{\lambda}=\mu+c \bar{\lambda}$ egyenletet kapjuk, amelyből a szóbanforgó Hawkes-folyamat létezésének alábbi szükséges (és egyben elégséges, ld. [10]) feltételét kapjuk:

$$
c=\int_{0}^{\infty} g(t) d t<1 .
$$

A Hawkes-folyamatok idegtudományi alkalmazásának, ezen belül az egysejtaktivitás modellezésének többek között az a meggondolás az alapja, hogy a neuronok burst-üzemmódja egyfajta feedback-hatásra utal. Jelen vizsgálódásunk célja, hogy egyváltozós Hawkes-folyamatok segítségével létrehozzunk egy, az idegsejtek tüzelését jól leíró, de egyszerü modellt, és azt statisztikailag értelmezzük. Ilyen 
eszközök birtokában várható annak feltérképezése, hogy bizonyos agyi történések - nevezetesen epilepsziás rohamok során - milyen utat járnak be az egyes tüzelési mintázatok paraméterei a paramétertérben. Az ML-becsléssel (ld. [11]) kapott paraméterekhez tartozó konfidenciaellipszoidok támpontot adhatnak a betegség szempontjából lényeges, különböző agyi állapotok detektálására, ld. [2, 6].

\section{Hawkes-folyamatok illesztése}

Hawkes-folyamatoknak valós, SUA-adatokhoz történő illesztése céljából tekintsük Hawkes-folyamatok egy paraméteres osztályát, ld. [11]:

$$
g(u)=\sigma \cdot e^{a u}, u \geq 0, \quad \text { ahol } \quad \sigma>0, a<0 .
$$

Ebben az esetben a (2) stabilitási kritérium azt jelenti, hogy $-\sigma / a<1$, vagy ekvivalens módon $\alpha:=a+\sigma<0$. Az így definiált $\alpha$ a stabilitásnak egyfajta mértéke (stability margin). Legyen $\eta=(\mu, a, \sigma)$, és tegyük fel, hogy az adatainkat ténylegesen egy Hawkes-folyamat definiálja, amelynek valódi paramétere $\eta^{*}$. Az $\eta^{*}$ becsléséhez vegyünk egy tetszőleges megengedett $\eta$ paramétert, amely tehát kielégíti az $a+\sigma<0<\mu$ feltételt, és definiáljunk egy $\lambda_{t}(\eta)$ intenzitásfüggvényt a

$$
\lambda_{t}(\eta)=\mu+\int_{0}^{t} g(t-s, \eta) d N_{s}=\mu+\int_{0}^{t} \sigma \cdot e^{a(t-s)} d N_{s}
$$

egyenlettel. Vegyük észre, hogy ha feltesszük, hogy a valódi pontfolyamatban a 0 időpont elött nincs esemény, azaz $d N_{t}=0$, ha $t \leq 0$, akkor ezen feltétel mellett $\lambda_{t}(\theta)=\lambda_{t}\left(\theta^{*}\right)$ minden $t \geq 0$-ra. A (feltételes) log-likelihood függvény kiszámításának alapja az a matematikailag pontosan megalapozható heurisztika, hogy minimális feltételek mellett egy pontfolyamat lokálisan olyan, mint egy Poissonfolyamat, ld. [1]. Ez alapján kapjuk, ld. [11], ill. [3], hogy a negatív log-likelihood a $[0, T]$ intervallumon, konstanstól eltekintve,

$$
L_{T}(\eta)=\int_{0}^{T} \lambda_{t}(\eta) d t-\int_{0}^{T} \log \lambda_{t}(\eta) d N_{t}
$$

A $\lambda_{t}(\eta)$ függvény meghatározásához minden $t$ értékre külön numerikusan ki kell számítani a (3)-beli integrált. Exponenciális válaszfüggvény esetén ez megkerülhető, ugyanis ha a (3) egyenlőségben $\mu$-t átvisszük a baloldalra, majd pedig $t$ szerint „differenciáljuk" az egyenletet, akkor a $T_{n-1}<t \leq T_{n}$ intervallumon amelynek belsejében nincs esemény - a (balról folytonos) intenzitásfüggvényre az alábbit kapjuk:

$$
\lambda_{T_{n-1+}}=\lambda_{T_{n-1}}+\sigma, \quad \lambda_{t}(\eta)-\mu=e^{a\left(t-T_{n-1}\right)}\left(\lambda_{T_{n-1+}}(\eta)-\mu\right) .
$$


Ilymódon az ML-becsléshez szükséges $\lambda_{t}(\eta)$ függvény a fenti intervallumon explicite kiszámítható a $\lambda_{T_{n-1}}(\eta)$ kezdeti érték ismeretében!

A Hawkes-folyamat természetes, fizikailag értelmezhető jellemzői a stabilitási türéshatár és az átlagos intenzitás, így exponenciális válaszfüggvény esetén egy természetes alternatív paraméterezés: $\theta=(\alpha, \sigma, \bar{\lambda})$. A becslés aszimptotikus pontosságának mértékét 95\%-os konfidenciaellipszoidokkal jellemezzük. A Fisher-mátrix általános paraméterezés mellett a (4) egyenlet alapján, az $\eta$ helyett a $\theta$ paramétert használva - továbbá egy alkalmas nagy számok erős törvényének érvényességét feltételezve - az alábbi módon számítható:

$$
I\left(\theta^{*}\right)=\lim _{T \rightarrow \infty} \frac{1}{T} \sum_{0<T_{n} \leq T} \frac{\lambda_{\theta T_{n}}\left(\theta^{*}\right) \cdot \lambda_{\theta T_{n}}^{T}\left(\theta^{*}\right)}{\lambda_{T_{n}}^{2}\left(\theta^{*}\right)},
$$

ahol a $\theta$ alsó index $\theta$ szerinti parciális deriváltat jelöl.

\section{Kísérleti eredmények}

A fenti - MATLAB-környezetben implementált - illesztési módszer müködésének vizsgálatához patkányhippokampusz-agyszeletekből származó mintegy 3 perces felvételek egysejt-aktivitását [8] használtuk fel. A kísérletesen megfigyelt 12 SUA-hoz rendelt paraméterhármasok megadják számunkra a paramétertér egy élettani szempontból releváns tartományát. Az 1. táblázatban referenciapéldaként két SUA-hoz tartozó becsült $(\alpha, \sigma, \bar{\lambda})$ Hawkes-paramétereket tüntettük fel, ahol $n$ a tüzelések számát jelöli.

\begin{tabular}{|c|c|c|c|c|}
\hline SUA & $n$ & $\alpha$ & $\sigma$ & $\bar{\lambda}$ \\
\hline \hline $\mathbf{3}$ & 1639 & $-24,72$ & 29,98 & 9,13 \\
\hline $\mathbf{5}$ & 609 & $-88,78$ & 24,22 & 3,39 \\
\hline
\end{tabular}

1. táblázat. Két kísérletes SUA Hawkes-paraméterei.

Az első referenciapélda adataihoz tartozó $L_{T}(\theta)$ költségfüggvényt (negatív loglikelihood függvényt), pontosabban annak metszeteit a 2. ábrán mutatjuk be, a metszeteket a becsült $\hat{\theta}_{T}$ egy-egy koordinátájának rögzítése mellett véve.

Összevetve az egyes SUA-khoz tartozó konfidenciaellipszoidokat, ld. 3. ábra, ill. azok térfogatait, empirikusan is megerösítést nyert az a tény, hogy kis mintaelemszám, és ebből adódó kis $\bar{\lambda}$ átlagos tüzelési gyakoriság esetén bizonytalanabb a becslés. Megjegyezzük, hogy a megyfigyelt SUA-k tüzelési rátája 0,3 és 8,5 Hz között, a kísérleti adatokból becsült $\bar{\lambda}$ átlagos tüzelési gyakoriság pedig 0,36 és 12,88 között változott. Levonható tehát az a következtetés, hogy a tüzelés dinamikájának becsülhetősége a feltételezetten rövid, roham előtti periódusban 


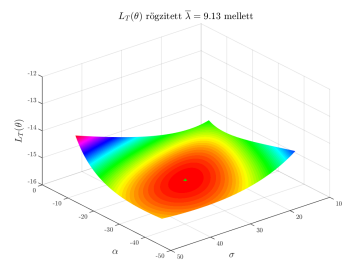

(a)

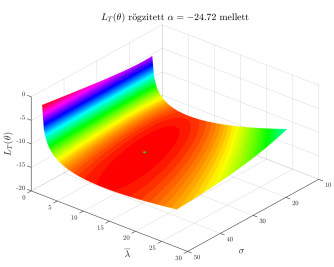

(b)

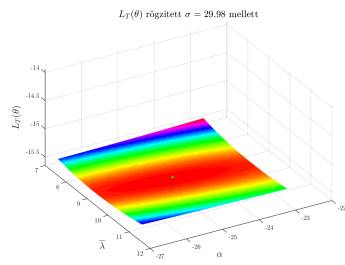

(c)

2. ábra. Egy referenciapéldához tartozó $\mathbf{L}_{\mathbf{T}}(\theta)$ költségfüggvény metszetfüggvényei.

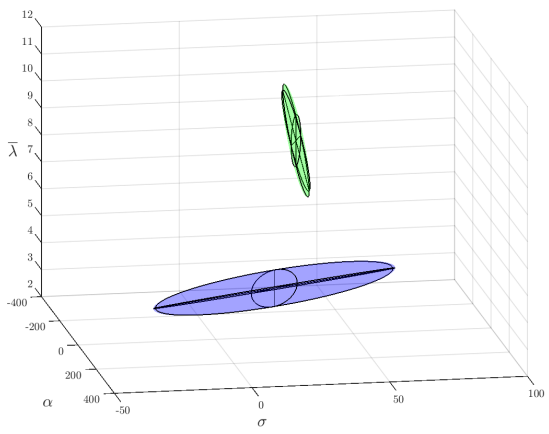

3. ábra. A referenciapéldák becslésének 95\%-os konfidenciaellipszoidja.

lényegesen függ a vizsgált SUA-tól. A Hawkes-folyamatok fenti osztálya paramétereinek ML-becslését, annak numerikus és statisztikai tulajdonságait fiziológiásan releváns paraméterekkel szimulált adatokon (ld. [11]) teszteltük. A dolgozatban vázolt metodika alkalmazhatóságának végső kritériuma, hogy az epilepsziás rohamok szempontjából releváns agyi állapotokat képes-e elkülöníteni. Ennek eldöntése egy még folyamatban lévő kutatásunk tárgya.

\section{Köszönetnyilvánítás}

A kutatás az Ipar 4.0 kutatási és innovációs kiválósági központ, GINOP2.3.2-15-2016-00002, az Innovatív informatikai és infokommunikációs megoldásokat megalapozó tematikus kutatási együttmüködések, PPKE ITK EFOP-3.6.2-162017-00013, és az Integrált kutatói utánpótlás-képzési program az informatika és számítástudomány diszciplináris területein, 3.6.3-VEKOP-16-2017-00002 címü és 
számú pályázati projektek, valamint a Nemzeti Agykutatási Program 2.0 (NAP 2.0: 2017-1.2.1-NKP-2017-00002) támogatásával jött létre.

A dolgozat végén az első szerző PhD-kutatási munkájához közvetlen és folyamatos mentori tevékenységet ellátó társzerzők életrajzának közlésére szorítkozunk.

\section{Hivatkozások}

[1] Bremaud, P.: Point Processes and Queues: Martingale Dynamics, Springer Verlag, New York (1981). DOI: 10.1002/bimj.4710300220

[2] Chornoboy, E. S., Schramm, L. P., And Karr, A. F.: Maximum likelihood identification of neural point process systems., Biological cybernetics, Vol. 59 No. 4-5, pp. 265-75 (1988). DOI: $10.1007 /$ BF00332915

[3] Daley, D. J. And Vere-Jones, D.: An Introduction to the Theory of Point Processes, Springer Science \& Business Media (2013). DOI: 10.1007/b97277

[4] Gadhoumi, K., Lina, J.-M., Mormann, F., and Gotman, J.: Seizure prediction for therapeutic devices: A review., Journal of neuroscience methods, Vol. (029), pp. 1-13 (2015). DOI: $10.1016 /$ j.jneumeth.2015.06.010

[5] Gerhard, F., Deger, M., and Truccolo, W.: On the stability and dynamics of stochastic spiking neuron models: Nonlinear Hawkes process and point process GLMs, Vol. 13 (2017), DOI: $10.1371 /$ journal.pcbi.1005390

[6] Hansen, N. R., Reynaud-Bouret, P., and Rivoirard, V.: Lasso and probabilistic inequalities for multivariate point processes, Bernoulli, Vol. 21 No. 1, pp. 83-143 (2015). DOI: 10.3150/13-BEJ562

[7] Hawkes, A. G.: Spectra of some self-exciting and mutually exciting point processes, Biometrika, Vol. 58 No. 1, pp. 83-90 (1971). DOI: 10.1093/biomet/58.1.83

[8] Hofer, K. T., Kandrács, Á., Ulbert, I., Pál, I., Szabó, C., Héja, L., and Wittner, L.: The hippocampal CA3 region can generate two distinct types of sharp wave-ripple complexes, in vitro, Hippocampus, Vol. 25 No. 2, pp. 169-186 (2015), DOI: 10.1002/hipo.22361

[9] Merricks, E. M., Smith, E. H., McKhann, G. M., Goodman, R. R., Bateman, L. M., Emerson, R. G., Schevon, C. A., And Trevelyan, A. J.: Single unit action potentials in humans and the effect of seizure activity, Brain, Vol. 138 No. 10, pp. 2891-2906 (2015), DOI: $10.1093 /$ brain/awv208

[10] Møller, J. and Rasmussen, J. G.: Perfect simulation of Hawkes processes, Advances in Applied Probability, Vol. 37 No. 3, pp. 629-646 (2005). DOI: 10.1239/aap/1127483739

[11] OzAKI, T.: Maximum likelihood estimation of Hawkes' self-exciting point processes, Annals of the Institute of Statistical Mathematics, Vol. 31 No. 1, pp. 145-155 (1979). DOI: 10.1007/BF02480272

[12] Schulze-Bonhage, A. And KüHn, A.: Unpredictability of Seizures and the Burden of Epilepsy, in: Seizure Prediction in Epilepsy: From Basic Mechanisms to Clinical Applications, pp. 1-10 (2008). DOI: 10.1002/9783527625192.ch1 


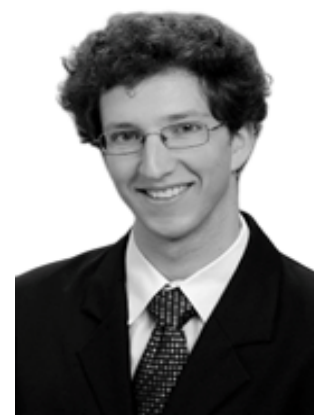

Dr. Perczel György 1989-ben született Budapesten. 2015ben summa cum laude minősítéssel diplomázott a Semmelweis Egyetem Általános Orvostudományi Karán. Még ugyanebben az évben Kvantitatív Modellezés és Informatikai Megalapozás oklevelet szerzett a Pázmány Péter Katolikus Egyetem Információs Technológiai és Bionikai Kara és a Semmelweis Egyetem közös képzése keretében. 2015-től a Pázmány Péter Katolikus Egyetem Roska Tamás Müszaki és Természettudományi Doktori Iskolájának hallgatója, 2018 óta az iskola doktorjelöltje. Kutatási területe Gerencsér

László DSc és Dr. Erőss Loránd PhD témavezetése mellett az extratemporalis epilepsziák biomarkereinek vizsgálata. Részt vesz a Nemzeti Agykutatási Programban (NAP 2.0) és tagja a Magyar Idegtudományi Társaságnak. 2019 januárjától az Országos Klinikai Idegtudományi Intézet idegsebész-rezidense.

\section{PERCZEL GYÖRGY}

Pázmány Péter Katolikus Egytem

Információs Technológiai és Bionikai Kar

1083 Budapest, Práter utca 50/A

Országos Klinikai Idegtudományi Intézet

1145 Budapest, Amerikai út 57.

perczel.gyorgy.miklos@itk.ppke.hu

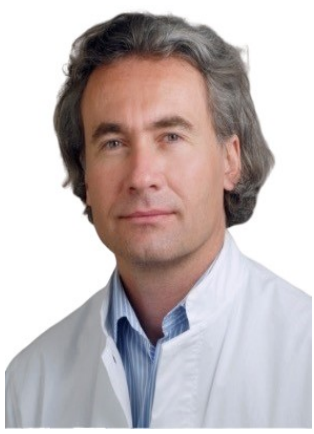

Dr. Erőss Loránd PhD neurológus, idegsebész, fájdalomterapeuta, főorvos az Országos Klinikai Idegtudományi Intézetben (OKITI). 1990-ben diplomázott a SOTE-n. 1995-ben neurológia, 2000-ben pedig idegsebészet szakvizsgát tett. 2010-ben szerzett egyetemi doktori fokozatot és 2019-ben habilitált a Semmelweis Egyetemen epilepsziasebészeti témában. Nemzetközi fájdalomterapeuta szakképesítéssel rendelkezik. Nevéhez füződik egy új neuromodulációs mütéti módszer hazai honosítása, egy új epilepsziasebészeti kivizsgálást segítő implantációs metodika kidolgozása, a

robot asszisztált idegsebészeti módszerek bevezetése hazánkban és a Közép-Kelet Európai régióban, illetve számos e témával kapcsolatos tudományos publikáció. Szakterülete az epilepsziasebészet, a fájdalom-, a mozgászavarok- és a spaszticitás sebészeti kezelése, valamint ezen kórképek neuromodulációs kezelése és ennek fejlesztése, kutatása.

ERŐSS LORÁND

Országos Klinikai Idegtudományi Intézet 1145 Budapest, Amerikai út 57.

Pázmány Péter Katolikus Egytem

Információs Technológiai és Bionikai Kar

1083 Budapest, Práter utca 50/A

l.g.eross@gmail.com 


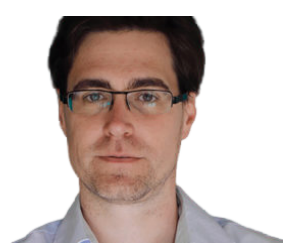

Dr. Fabó Dániel az Semmelweis Egyetem Általános Orvostudományi Karán végzett 2002-ben, ugyanitt szerzett idegtudományi PhD-fokozatot 2008-ban, majd 2011-ben neurológus szakvizsgát. Első munkahelye az OPNI Neurológiai Osztályán volt, aminek megszűnése után, 2007 óta az OKITI Neurológiai Osztályán dolgozik ideggyógyászként. Itt folyamatosan tagja az epilepszia, illetve epilepszia-sebészeti munkacsoportnak, neurológiai szempontból bevezette az ANT-DBS neuromodulációs kezeléseket epilepsziában, illetve felépítette az intraoperatív neuromonitorozási szolgálatot. 2013 óta kutatócsoportot vezet neurofiziológiai kutatási területen. Kutatási érdeklődése az epilepsziás és alvási EEG oszcillációk, valamint az agyi elektromos és mágneses ingerlések diagnosztikus és terápiás hasznosítása.

\section{FABÓ DÁNIEL}

Országos Klinikai Idegtudományi Intézet

1145 Budapest, Amerikai út 57.

fabo.daniel@gmail.com

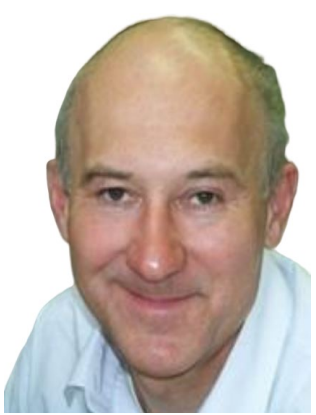

Gerencsér László egyetemi diplomáját az ELTE TTK matematikus szakán szerezte 1969-ben. 1970-től rövidebbhosszabb megszakításokkal az MTA SZTAKI-ban dolgozik az operációkutatás, majd a rendszer- és irányításelmélet témaköreiben. 1988 és 1991 között vendégprofesszor volt a kanadai McGill Egyetemen (Montreal, Quebec), 1997 és 2001 között pedig Széchenyi Professzori Ösztöndíjasként oktatott az ELTE TTK Valószínűségelméleti és Statisztika Tanszékén. Itt matematikus szakon elsőként oktatott modern pénzügyi matematikát. Több éven át tanított a Pázmány

Péter Katolikus Egyetem Információs Technológiai és Bionikai Karán is. Témavezetése mellett 8 tanítványa szerzett $\mathrm{PhD}$-fokozatot. Az MTA doktora címet 2000-ben kapta meg. Több cikluson át szerkesztőbizottsági tagja volt a SIAM Journal of Control and Optimization, ill. az IEEE Transactions on Automatic Control folyóiratok szerkesztőbizottságainak. Főbb kutatási területei: sztochasztikus rendszerek, változásdetektálás, pénzügyi idősorok, pontfolyamatok, gépi tanulás, elosztott számítási modellek.

GERENCSÉR LÁSZLÓ

MTA SZTAKI

1111 Budapest, Kende utca 13-17.

gerencser.laszlo@sztaki.mta.hu

\section{HAJNAL BOGLÁRKA}

Semmelweis Egyetem 1085 Budapest VIII. Üllői út 26.

Országos Klinikai Idegtudományi Intézet

1145 Budapest, Amerikai út 57.

haboglarka90@hotmail.com 


\section{SZABÓ CSILLA}

Pázmány Péter Katolikus Egytem

Információs Technológiai és Bionikai Kar

1083 Budapest, Práter utca 50/A

MTA Természettudományi Kutatóintézet

1117 Budapest, Magyar tudósok körútja 2.

szabo.csilla@itk.ppke.hu

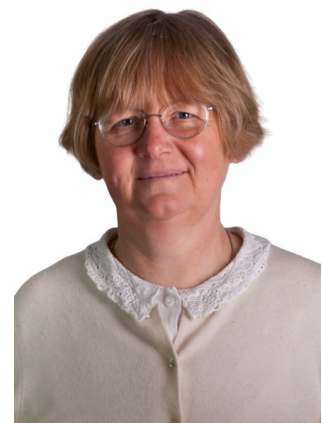

Vágó Zsuzsa az ELTE TTK matematikus szakán végzett 1982-ben, majd ugyanitt szerzett matematikusi PhD-fokozatot 1996-ban. Első munkahelye a Csepel Vas és Fémművek Irányítás- és Számítástechnikai Intézete volt, majd a BME Gépészkari Matematika Tanszéken volt tanársegéd. 1992 és 2006 között az MTA SZTAKI Rendszer- és Irányításelméleti, ill. az Operációkutatás és Döntési Rendszerek Kutatólaboratóriumában dolgozott. 2000 óta a Pázmány Péter Katolikus Egyetem Információs Technológiai és Bionikai Karán dolgozik, ahol több analízis tárgy oktatási anyagának kidolgozásával és oktatásával bízták meg, melyekhez egyetemi jegyzeteket is írt. Ezeket a tárgyakat azóta is folyamatosan oktatja, jelenleg egyetemi docensként. 2006 és 2015 között a kar tanulmányi dékánhelyettese volt. Kutatási érdeklődése a sztochasztikus rendszerek témaköréhez kötődik (identifikáció, véletlen keresés, pénzügyi idősorok, pontfolyamatok), ilyen témában társszerzője egy TÁMOP-jegyzetnek, és előadója több szabadon választható kurzusnak.

\section{VÁGÓ ZSUZSANNA}

Pázmány Péter Katolikus Egytem Információs Technológiai és Bionikai Kar 1083 Budapest, Práter utca 50/A

vago@itk.ppke.hu

\section{WITTNER LÚCIA}

Országos Klinikai Idegtudományi Intézet 1145 Budapest, Amerikai út 57.

MTA Természettudományi Kutatóintézet 1117 Budapest, Magyar tudósok körútja 2. wittner.lucia@ttk.mta.hu 


\title{
MODELING SINGLE-UNIT ACTIVITY OF EPILEPTIC BRAIN NETWORKS USING HAWKES PROCESSES
}

\author{
György Perczel, Loránd Erőss, Dániel Fabó, László Gerencsér, \\ Boglárka Hajnal, Csilla Szabó, Zsuzsanna Vágó, Lúcia Wittner
}

Epilepsy is one of the most common neurological disorder affecting around 50 million people worldwide. For approximately $30 \%$ of the patients satisfactory seizure control cannot be achieved with anti-epileptic drugs or surgical interventions. An alternative emerging technology is closedloop neurostimulation that might prevent the evolution of full-blown seizures, assuming that reliable seizure forecasting is available. With the aid of state-of-the-art microelectrodes single neuron action potentials can be recorded in the living brain giving insight into cellular-level changes during the onset of seizures. The firing patterns of individual nerve cells are modeled via the theory of point processes. In particular, Hawkes processes with exponential response function are fitted using maximum likelihood estimation (MLE) to neuronal spike-trains from rat hippocampal slice preparations. The accuracy and discriminating power of the MLE method is verified using the associated confidence ellipsoids on a large variety of physiologically relevant simulated data.

Keywords: point processes, Hawkes processes, point estimation, maximum likelihood estimation, applications to biology and medical sciences.

Mathematics Subject Classification (2010): 60G55, 62P10, 62F10. 